\title{
THE ROLE OF FATHER IN CHILD CARE IN THE RURAL FAMILY: PROVISION OF MATERIAL NEEDS
}

\author{
Lukash Bartosiak \\ ORCID iD 0000-0002-2980-7380 \\ Dr., graduated from the Faculty of Pedagogic \\ University of Warsaw \\ Krakow suburbs 26/28, 00-927 Warsaw, Poland
}

The article is part of the research project "Parental relations in rural areas". The article focuses on a small fragment of the project related to the role of the father in the process of a child's upbringing. The activities related to the organization of living conditions can be classified as the criteria for determining the participation of parents in childcare. A qualitative analysis of the collected research materials, preceding the theoretical introduction, provides modern knowledge on caring for the child, father's participation in the protection of children's health, cooking for the child, material support for children.

Key words: father; child; provision of material needs; material needs; a family; care; upbringing.

\section{INTRODUCTION}

The research presented in this article, based on qualitative methodology, was conducted in nineteen randomly chosen villages of Plock district. 37 respondents participated in it. The purpose was to determine paternal attitudes in a rural environment. The research does not meet the characteristics of representativeness. The collected research material deepens the scientific knowledge of the essence of a given phenomenon rather than its social scope. The data obtained during the analysis were compiled for a number of concepts that scientifically explain the correctness of the behavior and functioning of a man as a father and his attitudes. The social-scientific personality theory of J. Rotter (Gladowa, 1999), U. Bronfenbrenner's human ecology theory (Sosnowski, 2011), the socio-cognitive theory of A. Bandury (Gladowa, 1999) and the most important theoretical reference to the problem - "Cognitive concept of attitudes" by D. Crech, R. S. Crutchfield, E. L. Ballachey (Madrzycki, 1977) were taken into consideration. The study covered many issues. This article is devoted to a small fragment about the father in the childcare process. According to methodological assumptions, the selection of the sample was deliberately - random. The following characteristics were the criteria for targeted selection:

- fathers having a child in classes I - III of a primary school from the area of Plock district (rural area);

- $\quad$ fathers' age: men could not be over 40 ; - place of residence: the fathers under study lived in the countryside.

The criteria for random selection: rural communes of Plock district; random choice of schools (attended by the children of the fathers under study). The criteria that allowed me to determine the fathers' participation in the care activities actions related to the organization of a child's daily life (among other things, an 
average time during a working day dedicated to a child, his or her feeding, bathing, changing diapers, walking with a child in a pram, preparing meals, accompanying him or her while falling asleep, taking care of medical care, providing him or her with safe access to school and from school).

The research shows that caring for children is treated very seriously by respondents - as one of the most important areas of activity and a man's actualization as a father. All respondents declare their active and engaged participation in many activities and deeds aimed at the care of the child's life needs, they acknowledge their meaning. They also believe that these activities raise pride, satisfaction, and a sense of true masculinity in them. The respondents state that the father should, as far as possible, take care of the child as often as possible, with the utmost commitment, satisfaction, not only as a complement to his mother's activities, but replacing her in many cases. Declared caregiving actions are by no means a reason for the respondents to shame or feel the loss of the ideal of a man. Also, among the respondents there is no person to whom caring for the child would be a challenge that causes mental outrage, aggression, reluctance or avoidance of the child. Fathers' declarations give the knowledge that almost all caring activities performed with a child are, in addition to a serious duty, a source of satisfaction and pleasure. Among numerous care activities taken into account in the study are those that are performed with the baby from birth. These are the most important and necessary nursing and care actions for the life of the newborn. Analysis of the research material indicates that they include: bathing, swaddling and feeding.

\section{SECURING MATERIAL NEEDS}

All fathers under study work professionally. As it is known, the largest number of respondents are farmers (11), followed by drivers (6), private business owners (3) and teachers (3). Other men perform other non-agricultural jobs. Their work brings about the state of possession and ensures a sense of material safety of a family. All the fathers under study assess rather well the standard of living of their families. It arises from them, however, that the level of financial situation of the examined rural families is influenced by the number of children in the family. In the families with few children (one, two kids) - 28 of them were found during the research, the material situation, as evidenced by the fathers' statements, is stable and good. In these families there are greater opportunities for realizing children's material needs. In the remaining three (three and five children) family budget is poorer, there is more spending, which leads to the situation, as fathers say, where you cannot always afford meeting all the material needs of individual family members. Meeting only the basic needs of children is a disturbing phenomenon, as it can significantly limit the possibilities of using different cultural goods or developing one's own interests. These families are more likely to experience financial problems that are capable of disrupting their daily functioning and limiting the needs of their children. However, the men surveyed did not mention that their families lacked basic needs. Men and their families are in good housing and financial conditions. According to the research results, the type of occupation, working time and education do not have a significant impact on the families' declared financial situation.

The data obtained are quite optimistic, although somewhat contradictory with the research conducted over the years by TNS OBOP (The research shows 
that more than half of Poles (55\%) say that money is enough only for current expenditure. Every third person (31\%) declares that sometimes or for a long time they are unable to pay for basic services (rent, light, etc.) - source: http://www. tns-global.pl/archive-report/id/398) which informs about rather difficult financial situation of Poles, especially those living in the countryside. However, the area of research is a Polish village, which, after Poland's accession to the European Union, has been given the chance to grow through subventions and subsidies from the community. Farmers, as they say, benefit from the European Union, which contributed and is contributing to a permanent improvement in living conditions. Respondents who are farmers work together on farms together with their wives. They declare in this connection that they are not the sole breadwinners of their families. A similar situation occurs in the case of three men who have their own businesses. They work together with their wives. Only three of the respondents are the sole breadwinners of their families, and therefore the persons whose income determines the household's budget. One of these men works in a delegation abroad, the other one is a driver, while their wives raise three children in both cases. The constant absence of these fathers at home makes it impossible, as they say, for their wives to go to work. The third man works as a painter near his place of residence, while his wife is an unemployed person who is currently taking care of a second child - the newborn. Other respondents working outside agriculture are also not the only bread-makers of their families. Their wives work in different occupations. All respondents declare having a common home budget. As an indicator of the fathers' participation in creating material conditions for children and families, I accepted, first of all, the satisfaction of the material needs of the children (clothes, food, toys).

All fathers claim to provide material resources for all purchases related to the needs of the child and the whole family. Respondents can, however, be divided into two groups: those who do not directly participate in the purchase of children's clothing, food and toys, but only finance them, and those who do not only finance the purchase of the above items and products, but also participate in shopping. The first group includes as many as 14 men ( 4 farmers, 4 drivers, 3 teachers, a delegate employee, a company owner and a jeweler). These fathers declare that they never buy children's clothes and very rarely buy any toys and food not only for children but also for the whole family. Thus, there is the conclusion that their involvement in the family life is quite small. Such a relationship is not entirely justified in the case of the teachers who are in the group and who, unlike drivers, farmers or workers in the delegation, spend each afternoon with their families and would certainly find time for joint purchases and commitment to their own family. It can be tempted to suppose that staying home with a family often causes boredom to the everyday routine, which, in turn, causes the fathers to be reluctant to engage in many activities, such as direct participation in the meeting of a child's material needs, for example by shopping.

A man who performs the profession of a jeweler justifies the lack of involvement in the above mentioned activities by the excess of duties caused by casual work (the production of candles). However, such behavior is attributed to one particular occupational group, level of education or number of children in the family. The other group included the remaining twenty-three men. They are the fathers who declare rather frequent common purchases, as well as purchases without wife and direct involvement in satisfying the material needs of the child and family. Within 
this group, almost all the fathers declare, however, that they are involved in the purchase of food and toys, but the issue of buying clothing for a child lies with mothers. Buying food or toys gives them a lot of satisfaction, does not bring them off balance and does not give the rise to nervousness which is a characteristic feature of many men without patience, for example. It is necessary to be aware that buying toys or a variety of gadgets is not a daily activity. It is implemented at certain intervals, which in many cases are controlled and designated by these fathers. When it comes to family food supply, respondents point out that they are more engaged in big purchases made in supermarkets, for example, than in daily bread. Daily shopping, mostly bakery and dairy products, is usually done by the parent who is available on a given day or time, as a result of prior arrangements by the spouses. As far as clothes are concerned, the interviewers say that they do not have a taste, do not know about it, do not like this, do not like buying clothes and do not know the child's needs as nicely as the mother does.

Apart from the purchase of clothing, which may indicate at a rather stereotypical approach to this type of activity, the results of this research are, I think, to be regarded as optimistic. The fulfilled analysis allowed distinguishing the fathers carrying out maternity care directly and the fathers doing it indirectly. Fathers, who belong to the first group, buy baby clothes, food and toys by themselves or together with their wives. The indirect participation in this area of care shown by the fathers, who were included into the second group, mostly relies on the financing of the material needs of the child, mainly by the mother.

The research has shown that the factors (fathers' age, education, type of work, length of service, marital status, number of children in the family) determine the level and quality of care provided by fathers. Based on the three levels of father's involvement in child care created by T. Sosnowski (2011), I divided the subjects into three groups:

- $\quad$ Fathers with a high level of child care.

- Fathers with an average level of child care.

- Fathers showing low level of child care.

The first group includes fathers who spend five hours or more with their child during the weekday and recognize the need to stay with the child often; they are happy that working conditions allow this (6 respondents); they always cook lunches regardless of whether the wife is at home or at work, they prepare breakfasts and dinners, they like doing it, this gives them joy and satisfaction (3 respondents); they diligently share with their wives the obligation to provide a safe way to / from school for children (33 respondents, lack of fathers declaration of fulfillment of this duty without the participation of other family members); they diligently bathe the child with wife (33 respondents - no declaration of bathing the child by father alone); they diligently swaddle a child (37 - all participants of the research); they single-handedly take care of a child at the time of illness (2 respondents). They spend most free time with the child on Sunday (33 respondents - studies show that in the case of other days of the week, fathers do not spend leisure time with children and they do not try to make up for it).

The second group includes fathers who spend from two to four hours with their child during the working day, realizing the problem that it is too little time for their children, but they are unable to change the situation because of work (8 respondents). They can cook and do it sometimes, for example, when wife is at work, they sometimes prepare breakfasts and dinners and when it is said about 
dinner - they reheat more often than they cook (33); they do not participate in providing a child with a safe way to school ( 4 respondents); they diligently bathe the child with the wife (33 respondents - no declaration of bathing the child by father alone). They carefully swaddle children (37 - all respondents); they share the care for a sick child with wife (31 respondents). The spend most of their free time with the child on Sunday (33 respondents - studies show that in the case of other days of the week, fathers do not spend leisure time with children and they do not try to make up for it).

The third group includes fathers who spend very little time with their children during the working day - between one and two hours, and this situation is not a concern for them ( 8 respondents) or no more than one hour ( 7 respondents). In fact, they do not prepare meals, they do it sporadically, with reluctance, only when it is necessary, they do not like to do it, they cook because they have to, they often join to the preparation of many dishes and meals - they peel potatoes, make salads, prepare simple dishes for breakfast or dinner (1 respondent). They do not provide a child's safe way to school (4 respondents). They do not take part in bathing the baby ( 4 respondents). They do not take care of the baby at all during his or her illness ( 4 respondents). They spend very little leisure time with a child even on Sunday, or basically at all ( 4 respondents). They do not take part in bathing the baby ( 4 respondents).

As can be seen, few respondents are characterized by the last - low level of activity in the sphere of childcare. It can be concluded that fathers in rural environment are interested in taking care of the descendants and they take active part in it, at the same time helping the wife - the child's mother in this process. It can be concluded that the collected research material shows very optimistic knowledge about the subject matter. Unfortunately, as you can see, not all fathers are caring for the child. The main reason is the lack of time due to gainful employment. It may be believed that such conduct is a testimony to the existence of a traditional model of their families, which continues to address the issue of child custody towards the mother.

Unfortunately, many authors are questioning this knowledge of the vision of fatherhood, among others M. Sikorska cited in the article. Nevertheless, contemporary reports related to my research also point out that paternity is fulfilled by a man already at the time of conception, then in infancy, preschool, school, adolescence, adulthood, and even later. It is realized through participation and presence in the life of the offspring. It is hard to disagree with K. Gerson (Kwak, 2008) who claims that men are not born but become fathers. So it is not just "one of the culturally determined roles, but the hard work of the identity, conditioned by the needs of the child. Father's tasks already take place at the moment of conception (...)". The scope of duties of the father includes his participation in securing the child with the necessary material conditions for development, providing him or her with care, preparation for participation in culture, education. Fatherhood is not a moment in a man's life, but a process in a specific social context. The father cannot "happen", but he must "be" every day and every moment in the child's development. Characteristic for past times, the autocratic and instrumental treatment of fatherhood has undergone a transformation into the establishment of partnership and liberal relationship with the child. 


\section{REFERENCES}

Gładowa, A. (1999). Klasyczne i wspótczesne koncepcje osobowości. Kraków, Polska: Wydawnictwo Uniwersytetu Jagiellońskiego (pol).

Kwak, A. (2008). Rodzicielstwo między domem, prawem, stużbami społecznymi. Warszawa, Polska: Akademia Pedagogiki Specjalnej (pol).

Mądrzycki, T. (1977). Psychologiczne prawidłowości kształtowania się postaw. Warszawa, Polska: Wydawnictwa szkolne i Pedagogiczne (pol).

Sosnowski, T. (2011). Ojciec we współczesnej rodzinie. Kontekst pedagogiczny. Warszawa, Polska: Wydawnictwo Akademickie Żak (pol). 